Original Research Paper

\title{
Pemanfaatan Media Visual Untuk Meningkatkan Minat Belajar Anak dan Lansia Perempuan Melalui Focus Group Discussion Di Desa Baka Jaya
}

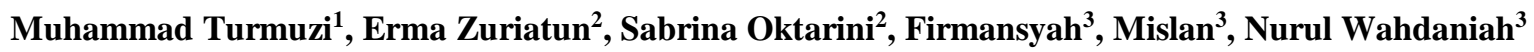

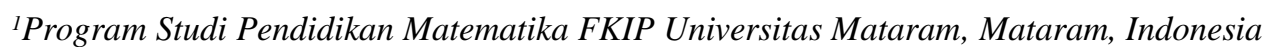 \\ ${ }^{2}$ Program Studi Pendidikan Bahasa Inggris FKIP Universitas Mataram, Mataram, Indonesia \\ ${ }^{3}$ Program Studi Pendidikan Sosiologi FKIP Universitas Mataram ${ }^{3}$, Mataram, Indonesia
}

https://doi.org/10.29303/jpmpi.v3i2.1335

Sitasi: Turmuzi, M., Zuriatun, E., Oktarini, S., Firmansyah., Mislan \& Wahdaniah, N. (2022). Pemanfaatan Media Visual Untuk Meningkatkan Minat Belajar Anak dan Lansia Perempuan Melalui Focus Group Discussion Di Desa Baka Jaya. Jurnal Pengabdian Magister Pendidikan IPA, 5(1)

\author{
Article history \\ Received: 11 Januari 2022 \\ Revised: 01 Februari 2022 \\ Accepted: 07 Februari 2022 \\ *Corresponding Author: \\ Muhammad Turmuzi, \\ Program Studi Pendidikan \\ Matematika FKIP Universitas \\ Mataram, Mataram, Indonesia \\ Email: tur.muzi@yahoo.co.id
}

\begin{abstract}
Desa Baka Jaya adalah salah satu desa yang berada di Kecamatan Woja Kabupaten Dompu Nusa Tenggara Barat. Posisinya cukup strategis karena merupakan jalur provinsi. Masyarakat di desa Baka Jaya teridri dari kalangan anak-anak dan lansia perempuan yang dominan masih kurang minatnya dalam belajar sehingga kebanyakan dari mereka masih ada yang buta huruf dan buta aksara. Dari pengamatan dilapangan, masih terdapat sejumlah anak-anak dan lansia perempuan yang tidak bisa membaca, menulis dan mengenal huruf Al-Qur'an maupun menghitung. Hal ini yang perlu mendapat sorotan dan perhatian dari mahasiswa KKN terpadu Universitas Mataram untuk segera memberi solusi yaitu solusi di bidang pendidikan. Sasaran implementasi pengajaran dengan model Focus Group Discussion dalam meningkatkan minat belajar, baca, tulis dan berhitung di desa Baka Jaya Kecamatan Woja Kabupaten Dompu ini adalah anak-ank usia dini serta Lansia Perempuan yang putus sekolah. Tujuannya untuk meningkatkan minat belajar anak dan lansia permpuan karena kebanyakan masyarakat masih sangat minim minat belajarnya. Metode pelaksanaan kegiatan adalah pengajaran dan pendampingan. Hasil dari kegiatan ini adalah telah terbentuk sekumpulan masyarakat, kelompok anak-anak dan lansia perempuan yang sudah terlatih, terampil dan minat belajarnya sudah meningkat. Hal ini dapat terlihat dari rajinnya mereka dalam mengikuti setiap kegiatan dan selalu mengerjakan tugas-tugas yang diberikan instruktur
\end{abstract}

Keywords: Minat Belajar, Focus Group Discussion, Media Visual, Desa Baka Jaya

\section{Pendahuluan}

Pembelajaran merupakan aspek kegiatan manusia yang kompleks, yang tidak sepenuhnya dapat dijelaskan. Pembelajaran secara sederhana dapat diartikan sebagai produk interaksi berkesinambungan antara pengembangan dan pengalaman hidup. Sedangkan pembelajaran dalam makna kompleks adalah usaha sadar dari seorang guru untuk membelajarkan siswanya yaitu mengarahkan interaksi siswa dengan sumber belajar lainnya untuk mencapai tujuan yang diharapkan. (Shalikhah et al., 2017, p. 10). Selanjutnya menurut pandangan konstruktivisme, belajar khususnya dalam pemahaman pengetahuan merupakan suatu proses yang aktif serta melalui pengalaman. Pandangan ini dikembangkan dari teori Piaget tentang perkembangan kognitif, biasa dikenal dengan Intelektual Development. Jadi belajar menurut pandangan konstuktivisme didefinisikan 
sebagai belajar yang menunjuk pada pandangan yang menyatakan bahwa pengetahuan itu dibangun di dalam pikiran peserta didik. (Wuryastuti, 2008).

Sedangkan Ketertarikan untuk belajar diartikan apabila seseorang yang berminat terhadap suatu pelajaran maka ia akan memiliki perasaan ketertarikan terhadap pelajaran tersebut. Ia akan rajin belajar dan terus memahami semua ilmu yang berhubungan dengan bidang tersebut, ia akan mengikuti pelajaran dengan penuh antusias dan tanpa ada beban dalam dirinya. Dalam pembelajaran juga perlu didukung oleh pengetahuan tentang teknologi. Hal ini diungkapkan oleh Turmuzi \& Kurniawan, (2021, p. 2486) bahwa kegiatan pembelajaran didasari pada pengetahuan tentang materi yang akan diajarkan (content knowledge), bagaimana mengajarkan suatu materi (pedagogical knowledge), dan pengetahuan tentang penggunaan berbagai teknologi (technological knowledge) yang ketiganya mempunyai irisan atau persinggungan untuk dapat mendukung satu sama lainnya.

Perhatian merupakan konsentrasi atau aktivitas jiwa seseorang terhadap pengamatan, pengertian ataupun yang lainnya dengan mengesampingkan hal lain dari pada itu. Jadi siswa akan mempunyai perhatian dalam belajar, jika jiwa dan pikirannya terfokus dengan apa yang ia pelajari. Motivasi merupakan suatu usaha atau pendorong yang dilakukan secara sadar untuk melakukan tindakan belajar dan mewujudkan perilaku yang terarah demi pencapaian tujuan yang diharapkan dalam situasi interaksi belajar. Pengetahuan diartikan bahwa jika seseorang yang berminat terhadap suatu pelajaran maka akan mempunyai pengetahuan yang luas tentang pelajaran tersebut serta bagaimana manfaat belajar dalam kehidupan sehari-hari. (Nurhasanah \& Sobandi, 2016, p. 131)

Minat belajar merupakan dorongan batin yang tumbuh dari seseorang siswa untuk meningkatkan kebiasaan belajar. Minat belajar akan tumbuh saat siswa memiliki keinginan untuk meraih nilai terbaik, atau ingin memenangkan persaingan dalam belajar dengan siswa lainnya. Minat belajar juga dapat dibangun dengan menetapkan cita-cita yang tinggi dan sesuai dengan bakat dan kemampuan siswa.(Lestari, 2014, p. 120). Menurut hasil penenlitian Putrayasa et al. (2014) menyimpulkan bahwa penerapan pembelajaran Discovery Learning dan minat belajar berpengaruh signifikan terhadap hasil belajar. Minat dan kebiasaan memiliki arti penting dalam meningkatkan ataupun menurunya prestasi belajar. Pencapaian siswa dalam sesuatu mata pelajaran adalah bergantung kepada minat. Siswa yang memiliki minat terhadap subjek tertentu memberikan perhatian yang lebih besar terhadap subjek tersebut. Minat merupakan faktor yang menentukan tercapainya tujuan belajar. Karena dengan adanya minat untuk belajar dalam diri siswa akan memudahkan guru dalam membimbing dan mengarahkan siswa. Dan siswa yang memiliki kebiasaan belajar cenderung hidup dengan penuh disiplin dan tanggung jawab dalam setiap tindakan belajarnya untuk mencapai prestasi dan hasil belajar yang tinggi.(Flora Siagian, 2015, p.124).

Desa Baka Jaya merupakan salah satu Desa dari 11 dan 3 Kelurahan yang terletak di wilayah Kecamatan Woja, Kabupaten Dompu, Nusa Tenggara Barat yang masyarakatnya dari kalangan anak- anak dan lansia perempuan dominan masih kurang minatnya dalam belajar, sehingga kebanyakan dari mereka masih kurang bisa membaca, menulis, berhitung dan mengaji. Kami mahasiswa KKN diharapkan dapat membantu pemerintah desa dan masyarakat setempat untuk mengembangkan pendidikan di Desa Baka Jaya, khususnya Dusun Woro Utara.

Dari pengamatan kami di lapangan, jumlah anak-anak dan lansia perempuan yang tidak bisa membaca, menulis dan mengenal huruf Al-Qur'an maupun menghitung sekitar 10-15 orang. Desa Baka Jaya memiliki jumlah total penduduk 4.945 Jiwa. Penduduk Desa Baka Jaya umumnya bergerak di bidang pertanian dan buruh. Kurang lebih penduduknya berprofesi sebagai petani, buruh tani, buruh harian lepas, peternak, pedagang dan pekerja swasta. Desa Baka Jaya terdiri dari 9 Dusun, diantaranya adalah Dusun Wodi, Rasanae Utara, Rasanae Selatan, Woro Utara, Woro Selatan, Mpuri, Bolobaka, Campa, dan Ama Maka.

Tujuan dari pelaksanaan KKN ini adalah untuk memberikan kesadaran dan pemahaman akan pentingnya pendidikan kepada masyarakat, karena dengan adanya pendidikan anak-anak dan ibu-ibu dapat meningkatkan produktivitas dan kualitas diri baik dalam kehidupan sosial individu dan kelompok, serta dapat menyesuaikan diri dengan kelompok masyarakat yang tingkat pendidikannya lebih tinggi. 


\section{Metode}

Proses pembelajaran menjadi semakin menarik dengan bantuan media yang dapat membuktikan konsep melalui percobaan. Alat peraga dapat membantu pembelajaran melalui metode demonstrasi. (Nurfiyani et al., 2016, p. 81). Model pembelajaran merupakan komponen utama bagi seorang guru dalam melaksanakan desain instruksional maupun implementasi pembelajaran, sebab model pembelajaran yang dipilih secara tepat sangat menentukan pencapaian daya serap terhadap prestasi belajar peserta didik.(Bintaro, 2018, p. 156). Salah satu model pembelajaran yang dapat diterapkan adalah model pembelajaran kooperatif Tipe Focus Group Discussion (FGD). Menurut hasil penelitian (Widiyati, 2019, p. 151) menyimpulkan bahwa penerapan model FGD dapat meningkatk aktivitas dan hasil bealjar peserta didik. Sedangkan hasil penelitian oleh Waluyati (2020, p. 89) menyebutkan bahwa penerapan fokus group discussian (FGD) dapat meningkatkan kemampuan memanfaatkan lingkungan sebagai sumber belajar pada guru SD.

Oleh sebab itu maka metode yang digunakan dalam kegiatan ini adalah dengan Cooperative Learning tipe Focus Group Discussion. Teknik ini melibatkan kelompokkelompok masyarakat, kelompok pemuda dan orang tua yang ada di Desa Baka Jaya. Pada awal kegiatan, kami melakukan sosialisasi terkait kegiatan pelaksanaan $\mathrm{KKN}$ dengan tujuan utama yaitu mengajar di desa.

Cooperative Learning adalah model pembelajaran yang mengutamakan eksistensi kelompok. Setiap peserta didik dalam kelompok memiliki tingkat kemampuan yang berbeda (tinggi, sedang, dan rendah). Model pembelajaran cooperative learning mengutamakan kolaborasi dalam memcahkan masalah untuk menerapkan pengetahuan dan keterampilan untuk mencapai tujuan pembelajaran.

Menurut Lie dalam Munawaroh (2016, p. 102) menyebutkan ciri-ciri pembelajarn Cooperative Learning adalah (1). Saling ketergantungan positif ; Dalam pembelajaran kooperatif, guru menciptakan suasana yang mendorong agar peserta didik merasa saling membutuhkan atau yang biasa disebut dengan saling ketergantungan positif yang dapat dicapai melalui: saling ketergantungan mencapai tujuan, saling ketergantungan menyelesaikan tugas, saling ketergantungan bahan atau sumber, saling ketergantungan peran, saling ketergantungan hadiah. (2). Interaksi tatap muka; Dengan hal ini dapat memaksa peserta didik saling bertatap muka sehingga mereka akan berdialog. Dialog tidak hanya dilakukan dengan guru tetapi dengan teman sebaya juga karena biasanya peserta didik akan lebih luwes, lebih mudah belajarnya dengan teman sebaya. (3). Akuntabilitas individual; Pembelajaran kooperatif menampilkan wujudnya dalam belajar kelompok. Penilaian ditunjukkan untuk mengetahui penguasaan peserta didik terhadap materi pelajaran secara individual. Hasil penilaian ini selanjutnya disampaikan oleh guru kepada kelompok agar semua kelompok mengetahui siapa kelompok yang memerlukan bantuan dan siapa yang dapat memberikan bantuan,maksudnya yang dapat mengajarkan kepada temannya. Nilai kelompok tersebut harus didasarkan pada rata-rata, karena itu anggota kelompok harus memberikan kontribusi untuk kelompnya. Intinya yang dimaksud dengan akuntabilitas individual adalah penilaian kelompok yang didasarkan pada rata-rata penguasaan semua anggota secara individual. (4). Keterampilan menjalin hubungan antar pribadi; Keterampilan sosial dalam menjalin hubungan antar peserta didik harus diajarkan. Peserta didik yang tidak dapat menjalin hubungan antar pribadi akan memperoleh teguran dari guru juga peserta didik lainnya.

Beberapa prinsip-prinsip penerapan FGD dalam rangka mengingkatkan kemampuan berbicara serta keterampilan berpikir kritis meliputi: (1) pengenalan dan simulasi FGD, (2) penentuan kelompok dan penyiapan topik FGD, (3) penggalian informasi dan peningkatan kosakata melalui kegiatan membaca, (4) praktik FGD, (5) refleksi dan pemberian masukan, 6) membuat catatan FGD, dan 7) presentasi lisan. Prinsipprinsip implementasi tersebut bisa dimodifikasi sesuai dengan kondisi di masing-masing konteks pembelajaran. (Hadi \& Junaidi, 2020, p. 132).

Mahasiswa KKN melakukan pengajaran dengan menggunakan Media Visual. Media visual merupakan media yang memberikan gambaran menyeluruh dari yang konkrit sampai dengan abstrak. Media visual ini lebih bersifat realistis dan dapat dirasakan oleh sebagian besar panca indera kita khususnya indera penglihatan. Manfaat yang kita dapat dalam penggunaan media ini adalah pemakaiannya yang efektif dan efisien, praktis, dan 
lebih cepat dipahami oleh peserta didik. Media Visual dapat berupa Media realita atau benda nyata, Model atau benda tiruan, dan media grafis seperti gambar.

Dalam proses pembelajaran diperlukan media, untuk itu kita harus menghetahui terlebih dahulu konsep abstrak dan konkret dalam pembelajaran. Pada hakekatnya, proses belajar mengajar adalah proses komunikasi, penyampaian pesan dari pengantar pesan ke penerima pesan. Pesan berupa isi atau ajaran yang dituangkan ke dalam simbol-simbol komunikasi baik secara verbal (kata-kata dan tulisan) maupun nonverbal. Proses tersebut dinamakan encoding. Penafsiran simbolsimbol komunikasi tersebut oleh peserta didik dinamakan decoding. Dalam penafsiran tersebut ada kalanya peserta didik berhasil dan ada kalanya tidak berhasil atau gagal. Kegagalan terjadi jika peserta didik tidak mampu memahami apa yang didengar, dibaca, dilihat, atau diamati. Kegagalan itu disebabkan oleh gangguan yang menjadi penghambat komunikasi yang dalam proses komunikasi dikenal dengan istilah bariers atau noise. Semakin banyak verbalisme, semakin abstrak pemahaman yang diterima. (Budiman, 2016, p. 176).

Menurut pendapat Fathurrohman dalam (Yusmiono, 2018, p. 4), fungsi penggunaan media dalam proses pembelajaran, yaitu: 1) menarik perhatian peserta didik, 2) membantu untuk mempercepat pemahaman dalam proses pembelajaran, 3) memperjelas penyajian pesan agar tidak bersifat verbalistis (dalam bentuk kata-kata tertulis atau lisan), 4) mengatasi keterbatasan ruang, 5) pembelajaran lebih komunikatif dan produktif, 6) waktu pembelajaran bisa dikondisi, 7) menghilangkan kebosanan peserta didik dalam belajar, 8) meningkatkan motivasi peserta didik dalam mempelajari sesuatu/menimbulkan gairah belajar, 9) melayani gaya belajar peserta didik yang beraneka ragam, serta 10) meningkatkan kadar keaktifan/keterlibatan peserta didik dalam kegiatan pembelajaran.

\section{Hasil dan Pembahasan}

\section{Hasil Kegiatan}

Berdasarkan hasil observasi selama kegiatan berlangsung, ada beberapa perubahan yang terjadi pada peserta didik terlihat dari pertama kami melakukan kegiatan mengajar baik dari kalangan anak- anak usia dini, lansia perempuan maupun masyarakat sekitar sangat antusias dengan adanya kegiatan kami.

Beberapa program kegiatan yang dilaksanakan di dalam pengabdian ini adalah sebagai berikut:

(a). Mengadakan Belajar Mengajar Anak Usia Dini. Pelaksanaan belajar mengajar di Dusun Woro Utara setiap hari Senin, Selasa, Rabu, Kamis dan Sabtu. Antusias anak-anak dusun Woro Utara begitu semangat. Selain itu Faktor pendukung pada pembelajaran Cooperative yang diadakan ini yaitu anak-anak lebih suka belajar sambil bernyanyi, bermain, bercerita dan sebagainya. Selain itu juga factor pengahambat dalam pembelajaran ini yaitu masih terdapat beberapa anak yang kadang tidak terlalu antusias dalam belajar dan sedikit sulit di kendalikan. Namun, setelah cukup melakukan pendekatan secara emosional anak-anak menjadi sangat baik dan penurut.

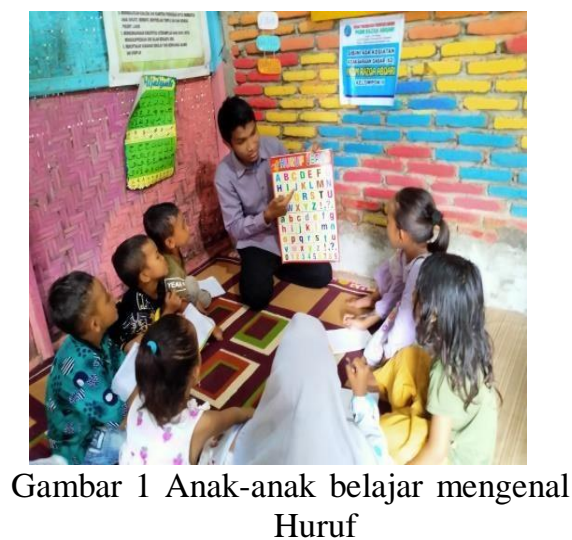

Huruf

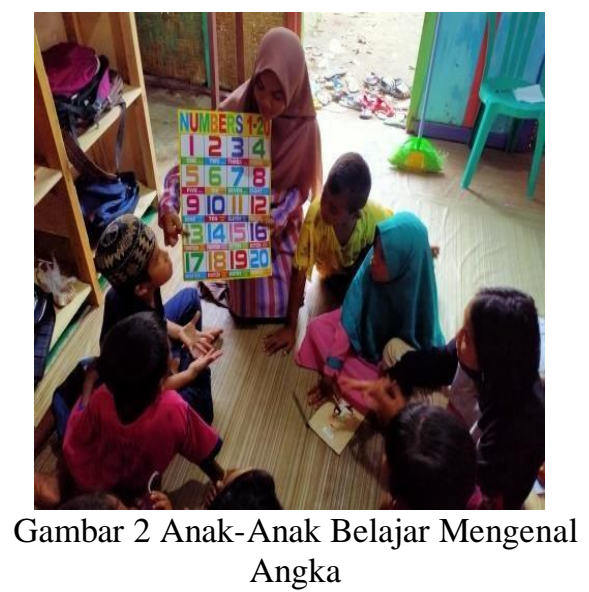




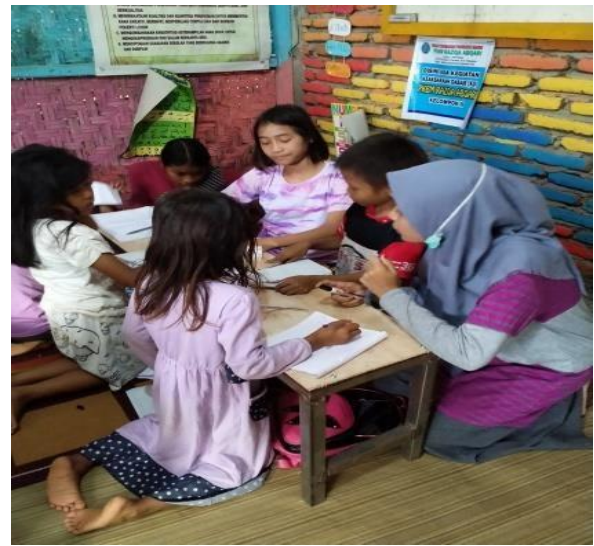

Gambar 3 Antusiasme anak- anak pada saat belajar Menulis kata

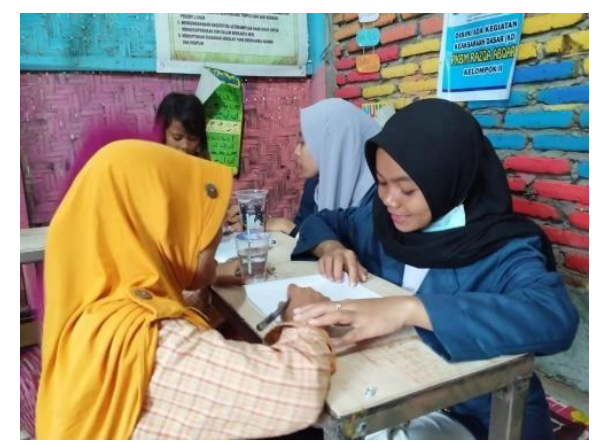

Gambar 4 Anak-anak Belajar Menghitung Dengan Media Realia Biji Asam

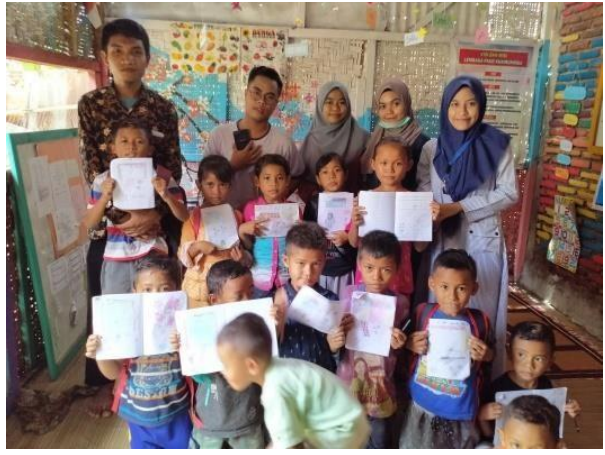

Gambar 5 Anak-anak Menggambar dan Mewarnai Sebagai Peningkatan Kreatifitas Anak.

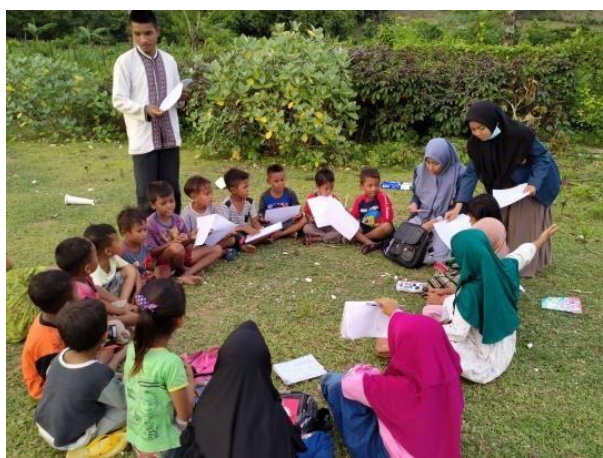

Gambar 6. Anak-anak Belajar di Luar Ruangan dan Menggambar Objek Dari Lingkungan Sekitar

(b). Mengajar Lansia Perempuan

Ibu merupakan madrasah pertama bagi anakanaknya. Oleh karena itu, pendidikan sangatlah penting bagi perempuan, sekalipun sudah memasuki kategori lansia. Hal ini dikarenakan pendidikan terhadap ibu dapat memberikan manfaat besar bagi kehidupan sehari-hari, baik interaksi social maupun bimbingan untuk anaknya dirumah. Sehingga potensi pendidikan perlu di kembangkan dalam hal belajar membaca, menulis, dan membaca Al-Qur'an. Dengan menggunakan pembelajaran kooperatif, proses belajar ibu-ibu dapat berlangsung dengan baik dan terarah. Hal ini karena di dalam kelompok belajar ibu-ibu terdapat beberapa anggota yang memiliki pengetahuan yang lebih dari anggota lain sehingga dapat menjadi tutor sebaya, dimana yang memiliki pemahaman kurang dapat belajar dari rekannya tersebut.

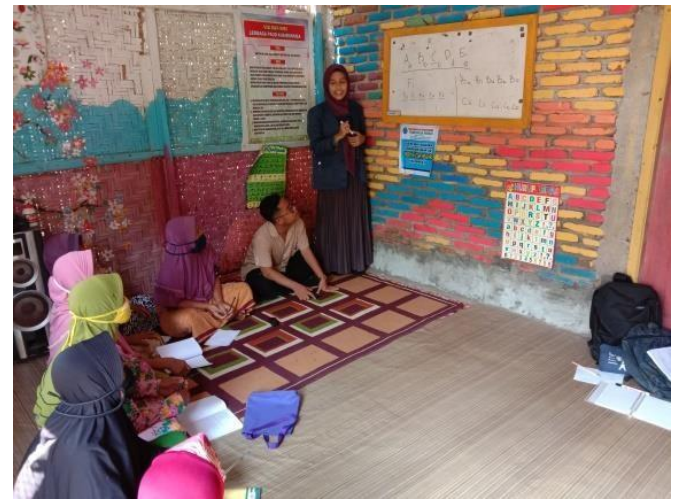

Gambar 7 Lansia Perempuan Belajar Mengenal Huruf dan Menulis 


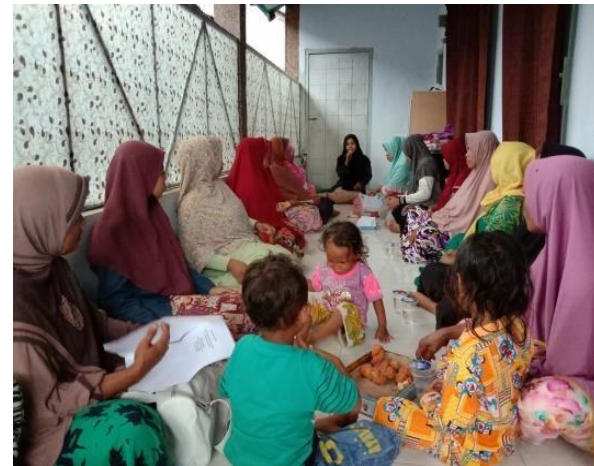

Gambar 8 Ibu-Ibu belajar mengajidan Sholawat bersama Mahasiswa

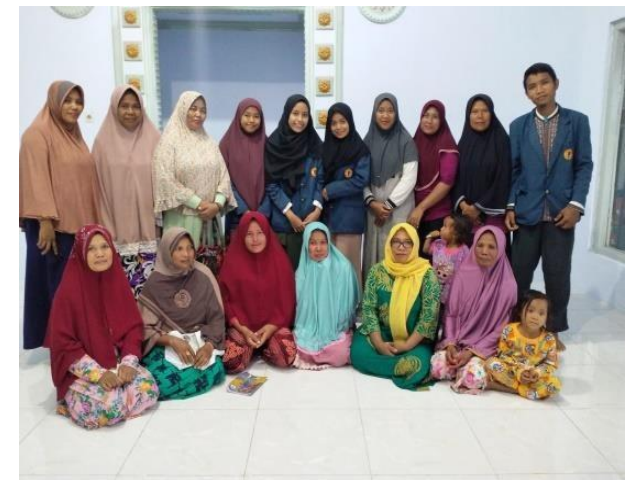

Gambar 9 Foto bersama setelahpengajian

\section{Pembahasan}

Pembelajaran anak usia dini selalu disajikan dengan ceramah. Dalam otak peserta didik terkadang mulai jenuh, dengan demikian kami mahasiswa KKN harus mencari inovasi yang baru untuk meningkatkan motivasi belajar peserta didik, ketika peserta didik termotivasi belajar maka hasil belajar pun akan meningkat. Salah satunya dengan menggunakan media dalam proses pembelajaran. Menurut Fitria (2014, p. 58) dengan penggunaan media pembelajaran dapat membatu untuk membangkitkan motivasi belajar peserta didik. Selain itu menurut Turmuzi et al., (2021, p. 907) dalam proses pembelajaran peserta didik diberi kesempatan untuk mengkonstruksi sendiri pengetahuan yang mereka miliki, sehingga peserta didik dapat saling berinteraksi melalui kelompok belajarnya.

Pembelajaran dengan menggunakan media audio visual berkaitan dengan indera penglihatan dan pendengaran sehingga dapat mengefektifkan kemampuan alat indera anak dan anak dengan mudah menangkap sebuah materi yang diangkan dalam video tersebut. Tujuannya untuk mengembangkan kemampuan kognitif dengan memberikan rangsangan berupa gambar bergerak dan suara, serta menyampaikan pesan untuk mempengaruhi sikap dan emosi. Dalam penggunaan media audio visual ini memiliki kelemahan dan kelebihan. Oleh sebab itu, penggunaannya perlu mempertimbangkan berberapa aspek penting yang menunjang kebersilannya.

Kelompok anak usia dini merupakan kelompok yang sangat strategis dan efektif dalam pembinaan karakter, hal ini harus menjadi kesadaran kolektif dari seluruh elemen bangsa ini. Karena masalah pendidikan anak usia dini sampai saat ini masih banyak menyisakan persoalan. (Rosada, 2016, p. 43). Gambar atau foto adalah media grafis yang paling sering dipergunakan untuk membantu menyampaikan materi pembelajaran kepada anak. Media ini memiliki berbagai kelebihan dibanding media grafis yang lain. Keuntungan tersebut yaitu; (1) bersifat konkret. Gambar atau foto dapat dilihat oleh anak dengan gambar dan warna yang menarik, jelas dan realistis menunjukkan materi atau pesan cerita yang disampaikan, (2) mengatasi ruang dan waktu. Untuk menunjukkan gambar karakter pada cerita tidak perlu melihat objek yang sesungguhnya melainkan cukup melihat gambar atau fotonya saja, (3) meminimalisasi keterbatasan pengamatan mata. untuk menerangkan objek tertentu yang sulit untuk diamati maka digunakanlah gambar atau foto, (4) dapat memperjelas suatu masalah. Gambar memungkinkan suatu masalah dipahami secara sama.

Secara umum dengan kami menggunakan media visual sebagai media pembelajaran anak anak menjadi tertarik terhadap materi yang kami sampaikan, mereka tidak cepat merasa bosan, mereka terlihat lebih antusias dan bersemangat dalam belajar. Berdasarkan hasil observasi selama kegiatan KKN yang kami lakukan, dapat dilihat bahwa kegiatan yang paling disukai murid merupakan kegiatan kerajinan tangan seperti mewarnai atau menempel kerajinan. Mereka terlihat mudah diatur ketika pelajaran yang menarik perhatian mereka, dari segi warna dan gambar. Pada kegiatan lain, anak terlihat lebih sulit diatur dank arena posisi duduk yang berserakan membuat guru sulit mengatur anak. Kendala yang dialami 
selama kegiatan adalah minimnya sarana dan prasarana. Kondisi ini juga sejalan dengan hasil kegiatan yang dilkasanakan oleh tim pengabdian (Gumulya et al., 2018, p. 70) yang menyebutkan bahwa dirasa perlu adanya sarana belajar yang dapat mendukung kegiatan anak agar lebih terorganisir dan meningkatkan karakter emosional anak melalui kegiatan yang paling mereka sukai.

Dalam kegiatan ibu-ibu lansia kami menghimbau agar ibu ibu segera langsung mengemukakan kepada tim KKN menanyakan bagaimana cara termudah agar ibu ibu yang memiliki keterbatasan dapat dengan mudah serta lancar dalam membaca huruf arab hijaiyah dengan bantuan multimedia. Kegiatan ini berlajan sesuai dengan jadwal, walaupun ada permintaan untuk perpanjangan durasi waktu kami dari tim berusaha semaksimal mungkin.

Untuk membantu ibu ibu lanjut usia dalam membaca huruf arab hijaiyah. Tim KKN kami memberikan pelatihan bagaimana multimedia diminati diberbagai usia dan bermanfaat untuk kita semua. Setelah ibu ibu memahami dan bisa mengoperasikan multimedia maka tim memberikan masukan metode yang membuat ibu ibu lanjut usia mudah dalam menghafal huruf hijaiyah. Kegiatan yang berlangsung materi ditambah dikarenakan banyak ibu ibu yang ingin diulang dan dilanjutkan kembali agar mudah menghafal. Terkait dengan kegiatan mengenal huruf Arab Hijaiyah hasil serupa ditunjukkan oleh kegiatan dari Wulan et al. (2018, p.51) bersama tim yang memberikan hasil yang sama dengan kegiatan Tim KKN kami. Hasil kegiatan mereka menyebutkan bahwa para ibu ibu lanjut usia dapat mempermudah dalam membaca huruf Hijaiyah dengan metode multimedia.

Dari hasil kegiatan dapat disimpulkan bahwa selama proses pembelajaran para peserta antusias mengikuti pembelajaran, ini bisa dilihat dari respon para peserta, keinginan peserta untuk belajar mengaji, bertanya jika ada kesulitan ketika mempraktekkan, karena didalam pembelajaran ini peserta diajarkan secara teori maupun praktek. Awalnya semua tampak kaku, tetapi berangsur seiring perjalan waktu latihan dan praktek peserta semakin baik bahkan lancar dalam pembacaan Al Quran. Kitab suci Al Quran disamping kita belajar cara membacanya kita juga dianjurkan untuk mempelajari dan mengamalkan isi dalam kandungannya. (belajar Tafsir Al AQuran). Menurut Rahmah. et al. (2020, p. 27) Al-Qur'an merupakan pedoman umat Islam dan membimbing manusia dalam mengarungi hidupnya sehingga sangat layak bila Al-qur'an mendapat perhatian istimewa. Diharapkan nanti para peserta bisa mengaji dengan rutin setiap hari dan dapat memahami kandungan Al Quran dengan mempelajari tafsir al quran pada dekade berikutnya.

\section{Kesimpulan}

Hasil dari kegiatan ini adalah telah terbentuk sekumpulan masyarakat, kelompok anakanak dan lansia perempuan yang sudah terlatih, terampil dan minat belajarnya sudah meningkat. Hal ini dapat terlihat dari rajinnya mereka dalam mengikuti setiap kegiatan dan selalu mengerjakan tugas-tugas yang diberikan instruktur.

Dengan kami Tim KKN menggunakan media visual sebagai media pembelajaran anak anak menjadi tertarik terhadap materi yang kami sampaikan, mereka tidak cepat merasa bosan, mereka terlihat lebih antusias dan bersemangat dalam belajar. Berdasarkan hasil observasi selama kegiatan KKN yang kami lakukan, dapat dilihat bahwa kegiatan yang paling disukai murid merupakan kegiatan kerajinan tangan seperti mewarnai atau menempel kerajinan.

selama proses pembelajaran para ibu ibu lansia antusias mengikuti pembelajaran, ini bisa dilihat dari respon para peserta, keinginan peserta untuk belajar mengaji, bertanya jika ada kesulitan ketika mempraktekkan, karena didalam pembelajaran ini peserta diajarkan secara teori maupun praktek.

Desa Baka Jaya adalah salah satu desa yang berada di Kecamatan Woja Kabupaten Dompu Nusa Tenggara Barat yang masyarakatnya dari kalangan anak- anak dan lansia perempuan dominan masih kurang minatnya dalam belajar, sehingga kebanyakan dari mereka masih kurang bisa membaca, menulis menghitung dan mengaji. Kami mahasiswa KKN diharapkan dapat membantu pemerintahan desa dan masyarakat setempat untuk membantu mengembangkan pendidikan khususnya di Dusun Woro Utara, Desa Baka Jaya. 


\section{Daftar Pustaka}

Bintaro, T. Y. (2018). Penerapan Pembelajaran The Power of Two Untuk Meningkatkan Minat pada Mata Pelajaran Matematika. SAIN SOSIAL DAN HUMANIORA, 2(1), 145-157.

Budiman, H. (2016). Penggunaan Media Visual Dalam Proses Pembelajaran. Al-Tadzkiyyah: Jurnal Pendidikan Islam, 7(November), 171182.

Fitria, A. (2014). PENGGUNAAN MEDIA AUDIO VISUAL DALAM. Cakrawala Dini, 5(2), 57-62.

Flora Siagian, R. E. (2015). Pengaruh Minat dan Kebiasaan Belajar Siswa terhadap Prestasi Belajar Matematika. Formatif: Jurnal Ilmiah Pendidikan MIPA, 2(2), 122-131. https://doi.org/10.30998/formatif.v2i2.93

Gumulya, D., Adiputra, R., Pengajar, S., Produk, D., \& Harapan, U. P. (2018). KEGIATAN PENGABDIAN KEPADA MASYARAKAT: Perancangan Sarana Pendidikan Anak Usia Dini Untuk Sekolah Cahaya Al-fuqron, Desa Gunung Sari, Kecamatan Mauk, Kabupaten Tanggerang. 15(1), 63-78.

Hadi, M. J., \& Junaidi, M. (2020). Prinsip dan Langkah-langkah Penerapan Focus Group Discussion Untuk Meningkatkan Keterampilan. Jurnalistrendi: Jurnal Linguistik, Sastra, Dan Pendidikan, 5(2003), 126-134.

Lestari, I. (2014). Pengaruh Waktu Belajar Dan Minat Belajar. Jurnal Formatif, 3(2), 115125.

Munawaroh, S. (2016). Model Pembelajaran Kooperatif ( cooperative learning ) Dalam Strategi Belajar Mengajar Bahasa Arab. Prosiding Konferensi Nasional Bahasa Arab 2, 100-116.

Nurfiyani, N. T., Sopyan, A., \& Hardyanto, W. (2016). Penerapan Model Pembelajaran Kooperatif Tipe Student Team Achievement Division ( STAD ) Berbantu Media Animasi. Unnes Physics Education Journal, 5(3).

Nurhasanah, S., \& Sobandi, A. (2016). Minat Belajar Sebagai Determinan Hasil Belajar Siswa. Jurnal Pendidikan Manajemen Perkantoran, $1(1), \quad 128$. https://doi.org/10.17509/jpm.v1i1.3264

Putrayasa, I. M., Syahruddin, H., \& Mergunayasa, I. G. (2014). Pengaruh Model Pembelajaran
Discovery Learning Dan Minat Belajar Terhadap Hasil Belajar Ipa Siswa. Jurnal Mimbar PGSD Universitas Pendidikan Ganesha, 2(1), 1-11. http://ejournal.undiksha.ac.id/index.php/JJPG SD/article/view/3087

Rahmah., Fithri, R., \& Sintya, D. (2020). Pembelajaran Iqro Bagi Ibu Majlis Ta'lim. Dedication Journal, 1(1), 27-32.

Rosada, U. D. (2016). Memperkuat Karakter Anak Melalui Dongeng Berbasis Media Visual. Jurnal CARE (Children Advisory Research and Education), 04(1), 42-49.

Shalikhah, N. D., Primadewi, A., \& Iman, M. S. (2017). Media Pembelajaran Interaktif Lectora inspire Sebagai Inovasi Pembelajaran. WARTA LPM, 20(1), 9-16. https://doi.org/10.24042/djm.v1i2.2583

Turmuzi, M., Dasing, A. S. H., Baidowi., \& Junaidi. (2021). Analisis Kesulitan Belajar Mahasiswa Secara Online ( E-Learning ) Selama Masa Pandemi Covid-19. Edukatif: Jurnal Ilmu Pendidikan, 3(3), 900-910. https://doi.org/:

https://doi.org/10.31004/edukatif.v3i3.482

Turmuzi, M., \& Kurniawan, E. (2021). Kemampuan Mengajar Mahasiswa Calon Guru Matematika Ditinjau dari Technological Pedagogical and Content Knowledge (TPACK) pada Mata Kuliah Micro Teaching. Jurnal Cendekia: Jurnal Pendidikan Matematika, 5(3), 2484-2498. https://doi.org/10.31004/cendekia.v5i3.881

Waluyati, M. (2020). Penerapan Fokus Group Discussian ( $F G D$ ) Untuk Meningkatkan Kemampuan Memanfaatkan Lingkungan Sebagai Sumber Belajar. 8(1), 80-91.

Widiyati. (2019). Focus Group Discussion ( FGD ) untuk Meningkatkan Aktivitas dan Hasil Belajar Kompetensi Ketenagakerjaan Pe- serta Didik di SMP N 7 Purworejo. Indonesian Journal of History Education, 7(2), 146-153.

Wulan, R., Saputra, E., \& Haries, A. (2018). Pengembangan Metode Cepat Membaca Huruf Hijaiyah Berbasis Multimedia Dalam Rangka Pemberantasan Buta Huruf Pada Lansia. Jurnal PKM: Pengabdian Kepada Masyarakat, 01(01), 48-54.

Wuryastuti, S. (2008). Inovasi Pembelajaran IPA di Sekolah Dasar. Jurnal Pendidikan Dasar, 9(April), 
http://103.23.244.11/Direktori/JURNAL/PEN DIDIKAN_DASAR/Nomor_9-

April_2008/Inovasi_Pembelajaran_IPA_di_Se kolah_Dasar.pdf

Yusmiono, B. A. (2018). MEDIA Pembelajaran Visual Terhadap Hasil Belajar Mahasiswa Program Studi Pendidikan Geografi. Faktor Jurnal Ilmiah Kependidikan, 5(1), 1-8. 